TINA PERIĆ, Ph.D. Student ${ }^{1}$

(Corresponding author)

E-mail: tina.peric@pfst.hr

PAVAO KOMADINA, Ph.D. ${ }^{2}$

E-mail: komadina@pfri.hr

NIKOLA RAČIć, Ph.D. ${ }^{1}$

E-mail: nikola@pfst.hr

1 University of Split, Faculty of Maritime Studies

Ruđera Boškovića 37, 21000 Split, Croatia

2 University of Rijeka, Faculty of Maritime Studies

Studentska ulica 2, 51000 Rijeka, Croatia
Traffic and Environment (Ecology)

Preliminary Communication

Submitted: Mar. 9, 2016

Accepted: July 12, 2016

\title{
WASTEWATER POLLUTION FROM CRUISE SHIPS IN THE ADRIATIC SEA
}

\begin{abstract}
The global growth of cruise tourism has brought increasing concern for the pollution of the marine environment. Marine pollution from sanitary wastewater is a problem especially pronounced on large cruise ships where the number of people on board may exceed 8,000. To evaluate future marine pollution in any selected period of time it is necessary to know the movement of ships in the Adriatic Sea. This paper presents the problem of marine pollution by sanitary wastewater from cruise ships, wastewater treatment technology and a model of cruise ship traffic in the Adriatic Sea considering MARPOL Annex IV areas of limited wastewater discharge. Using the model, it is possible to know in advance the routes of the cruisers and retention time in certain geographic areas. The data obtained by this model can be used as input parameters for evaluation model of wastewater pollution or for evaluation of other types of pollution from cruise ships.
\end{abstract}

\section{KEY WORDS}

cruising tourism; environmental protection; MARPOL Annex IV; sanitary wastewater;

\section{INTRODUCTION}

The Adriatic Sea is considered as a closed type of sea and therefore it is especially vulnerable to all kinds of pollution. Tourism, as a strategic sector of the Croatian economy, is based on the purity of Adriatic Sea. The share of "sun and sea" as the dominant product of Croatian tourism has not fallen below $85 \%$ of the physical volume in the total Croatian tourism product for years [1]. Croatia depends on tourism more than any other EU member country, even more than Malta, Cyprus and Greece, as proved by the data given in the foreign exchange revenue achieved by tourism in Croatia, which is the highest in Europe with 17 percent of Gross Domestic Product (GDP).

According to the Report on the environmental situation in the Republic of Croatia from 2007, the number of cruise ships, the number of passengers and the number of days in Croatian ports have not caused substantial environmental impacts, considering high standards of waste management on large cruise ships, although it emphasizes the problem of wastewater management from the vessels which is not completely solved in a satisfactory manner [2].

All ships at sea generate sanitary wastewater. However, the problem is particularly pronounced on large cruise ships because with their capacity of persons carried they are the size of small cities. Wastewater on cruise ships is generated in large quantities. That is why the method of wastewater management on board and the quality of wastewater discharged into the sea is very important.

The problem of discharge and storage of sanitary wastewater from vessels, as well as equipment and certificates that vessels must obtain in order to satisfy the prescribed standards, has been regulated by Annex IV of MARPOL Convention. Annex IV regulates standards for the discharge of sanitary wastewater according to three areas of navigation: sea area in a distance until 3 nautical miles (M) from the nearest land; sea area between 3 and $12 \mathrm{M}$ from the nearest land; sea area beyond $12 \mathrm{M}$ from the nearest land. However, legislation has been treating merchant navy ships with usually 30 persons on board equally as cruise ships where the number of persons on board may exceed 8,000 people. Therefore, besides the international regulations, some states have set forth their own regulations which are stricter, aiming to better protect their particularly sensitive areas, since the internationally recognized regulations have their disadvantages and there is still room for improvement [3].

Given the constant increase in cruise ship traffic globally, as well as an increase in ships themselves and their capacities, an increasing need is created for effective assessment of marine pollution by wastewater from cruise ships. Studying the literature it was 
observed that there is no model that could predict the pollution of certain sea areas from wastewater by knowing planned cruise ship traffic in that area.

The aim of this paper is to analyse one-year survey of cruise ship traffic in the Adriatic Sea and to create a model of cruise ships traffic in the Adriatic Sea considering MARPOL Annex IV areas of limited wastewater discharges. The model will provide prediction of cruise ships retention in the Annex IV navigation zones on a specific geographic area and in the selected period of time as the basis for assessing pollution of that area from wastewater.

\section{CRUISE WASTEWATER TREATMENT AND DISCHARGE TECHNOLOGY}

Wastewater on the ship can be divided into sanitary and oily bilge wastewater. Oily bilge water is a mixture of water, oily fluids, lubricants, cleaning fluids and other similar wastes that are collected in the ship's bilge tank and produced by main and auxiliary machinery, boilers and other mechanical machines. As oily water it is regulated in Annex I of MARPOL Convention.

Sanitary wastewater in order to increase efficiency and disposal is divided into black water or sewage and grey water. Black water is discharge from all types of toilets and urinals; discharge from the medical rooms; discharge from spaces with live animals, and any other wastewater if mixed with these discharges and it is regulated by Annex IV of MARPOL Convention. Grey water contains water from sinks, baths, showers, washing machines, saunas, swimming pools, sinks and water generated from washing ship's surface and it is not recognized as pollutant by the International Maritime Organization (IMO).

The quality of sanitary wastewater is determined by the amount of certain substances and energy contained by the wastewater. It should be noted that depending on their source from the ship all wastewater contains various amounts and concentrations of waste products that are characterized with respect to their physical, chemical and microbiological properties. There are a number of indicators, but their impact on the marine environment and human health distinguishes the following most important factors of wastewater quality: thermotolerant coliform, total suspended solids (TSS), 5-day biochemical oxygen demand (BOD5), chemical oxygen demand (COD), pH value and chloral residual. Concentrations of these factors in the wastewater effluent are directly dependent on the wastewater treatment system installed on the ship.

The quantity of discharged wastewater depends on the following factors:

- capacity of the ship: the number of passengers and crew;

- working mode of the ship.
Ship capacity allows us to calculate the total number of people on board in a given area at a given time. Taking into account the results of previous studies [4], that one person on board produces $31.8 \mathrm{I} /$ day of black water and $253 \mathrm{l} /$ day of grey water, it is possible to calculate how much black and grey wastewater is generated at a given point in time in a particular area.

The ship at sea has 4 modes of operation due to the discharge of wastewater:

MODE 1: Ship's wastewater is not discharged - it is kept in the ship's wastewater tanks;

MODE 2: Ship is discharging wastewater purified by advanced wastewater treatment plant installed on board; MODE 3: Ship is discharging partially treated wastewater (comminuted and disinfected), and

MODE 4: Ship is discharging untreated wastewater directly into the sea.

Ship's operation mode is directly dependent on the type of wastewater treatment system installed on board because the system performance must meet legal regulations for each MARPOL Annex IV area of navigation. For wastewater treatment ships can be equipped with: marine sanitation device, MSD or advanced wastewater treatment system, AWT. Table 1 shows the requirements of Annex IV of MARPOL Convention for the quality of sanitary wastewater effluent according to the areas of navigation as well as a minimal appropriate ship's operation mode.

MSD systems process exclusively black water while the grey water is discharged untreated. Most AWT systems treat both grey and black water. Testing of AWT system concluded that they comply with the most stringent standards for wastewater discharges. Therefore, according to MARPOL, ships with installed AWT systems can continuously discharge wastewater (Mode 2). However, with some of the AWT systems, it is possible to discharge partially treated wastewater, so users can choose after which stage of treatment they discharge. It means that it is possible to discharge fully treated wastewater in the $3 \mathrm{M}$ area and partially processed wastewater in 3-12 $\mathrm{M}$ area, or to use full wastewater treatment all the time.

Outside of $12 \mathrm{M}$ from the nearest land or outside the territorial sea, Annex IV allows the discharge of untreated raw sewage, provided that the ship is operating at a speed of no less than 4 knots. Marine Environment Protection Committee Resolution MEPC.157(55) of the MARPOL Convention defines a standard for the maximum permissible discharge rate of untreated sewage according to the following formula [8]:

$$
D R_{\max }=0.00926 \cdot V \cdot D \cdot B\left[\frac{m^{3}}{h}\right]
$$

where: 
Table 1 - Comparison of MARPOL's Annex IV effluent standards according to the areas of navigation and minimal appropriate ship's operation mode

\begin{tabular}{|c|c|c|c|c|c|c|c|}
\hline \multirow[b]{2}{*}{$\begin{array}{l}\text { MARPOL's Annex } \\
\text { IV areas of navi- } \\
\text { gation }\end{array}$} & \multicolumn{6}{|c|}{ Quality standards of sanitary wastewater effluent } & \multirow[b]{2}{*}{$\begin{array}{c}\text { Appropriate ship's } \\
\text { operation mode }\end{array}$} \\
\hline & \begin{tabular}{|c|} 
Thermo- \\
tolerant \\
Coliform \\
[in $100 \mathrm{ml}]$ \\
\end{tabular} & $\begin{array}{c}\text { TSS } \\
{[\mathrm{mg} / \mathrm{l}]}\end{array}$ & $\begin{array}{l}\text { BOD5 } \\
{[\mathrm{mg} / \mathrm{l}]}\end{array}$ & $\mathrm{COD}[\mathrm{mg} / \mathrm{l}]$ & $\mathrm{pH}$ value & $\begin{array}{l}\text { Chloral } \\
\text { residual } \\
{[\mathrm{mg} / \mathrm{l}]}\end{array}$ & \\
\hline $\begin{array}{c}3 \mathrm{M} \text { area } \\
\text { (to } 1.1 .2010)^{*}\end{array}$ & 250 & 100 & 50 & / & / & 0.5 & $\begin{array}{l}\text { MODE } 1 \text { or } \\
\text { MODE } 2\end{array}$ \\
\hline $3 \mathrm{M}$ area & 100 & $\begin{array}{c}35 \cdot \\
Q_{i} / Q_{e}{ }^{* *} \\
\end{array}$ & $\begin{array}{c}25 \cdot \\
Q_{i} / Q_{e}\end{array}$ & $\begin{array}{c}125 \\
Q_{i} / Q_{e}^{* *}\end{array}$ & $6-8.5$ & 0.5 & $\begin{array}{l}\text { MODE } 1 \text { or } \\
\text { MODE } 2\end{array}$ \\
\hline 3-12 M area & \multicolumn{6}{|c|}{ Ship is discharging comminuted and disinfected sewage } & MODE 3 \\
\hline Area outside $12 \mathrm{M}$ & \multicolumn{6}{|c|}{$\begin{array}{l}\text { Ship is discharging untreated sewage while en-route and proceeding at a } \\
\text { speed not less than } 4 \text { knots. The maximum permissible discharge rate is given } \\
\text { in Equation } 1\end{array}$} & MODE 4 \\
\hline \multicolumn{8}{|c|}{$\begin{array}{l}\text { * Applies to sewage treatment plants installed on board before } 1 \text { January } 2010 \\
* * \text { Where dilution is essential to a treatment process the effluent standards should be adjusted proportionally using } \\
\text { dilution compensation factor } Q_{i} / Q_{e} \text { to take account of dilution } Q_{d} \text {, where } Q_{i} \text { is influent, liquid containing sewage and grey } \\
\text { water to be processed by treatment plant, and } Q_{e} \text { is effluent, treated wastewater produced by treatment plant. }\end{array}$} \\
\hline
\end{tabular}

Source: data synthesized by authors from [5, 6, 7]

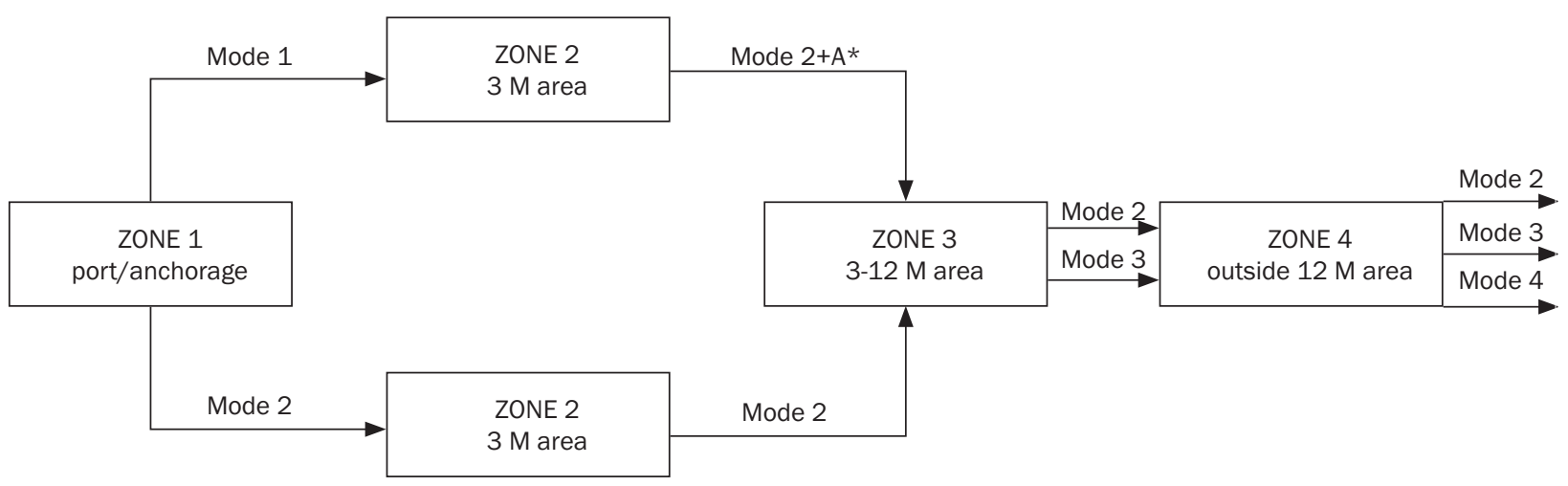

Figure 1 - Possible combinations of ship operation modes according to MARPOL Annex IV areas of limited wastewater discharges

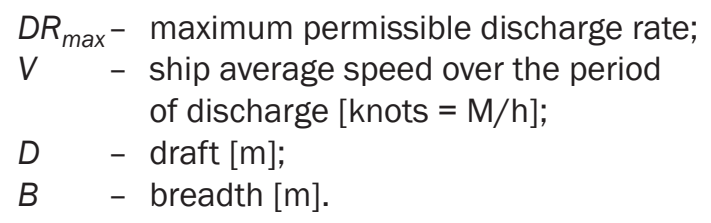

Every ship on its voyage uses one or a combination of several operating modes, Figure 1. By knowing the effluent quality of each of the modes and comparing different scenarios with those by the minimum requirements of MARPOL's Annex IV, guidelines for future effluent standards for cruises can be developed and pollution of a certain area can be evaluated.

For the evaluation of pollution of the Adriatic Sea it is necessary to understand the movement of cruise ships considering MARPOL Annex IV navigation areas of limited discharges. For this purpose, based on the monitoring of movement of cruisers in the Adriatic a model of cruise ships traffic for the Adriatic has been developed in order to evaluate pollution of any selected area of navigation for the chosen period of time in the future, knowing only the input parameters: cruisers itineraries, estimated time of arrival, ETA, and estimated time of departure, ETD for the chosen period of time.

\section{RESULTS OF THE SURVEY OF CRUISE SHIP TRAFFIC IN THE ADRIATIC SEA}

Movement of cruise ships in the Adriatic is obtained by monitoring the traffic of cruisers during the period of one year (1.8.2014 - 31.7.2015). For this survey the limit is set for the capacity of the ships and observed were only those ships carrying more than 500 passengers as relevant to the impact on the quantity of wastewater discharged. Traffic is monitored using an Internet monitoring system "Marine Traffic". 
The movement of cruise ships in the Adriatic Sea begins and ends in the Strait of Otranto. The boundary of the Adriatic and Ionian Sea, depending on the source, is defined in many ways. For research purposes the boundary is defined as a line between Cape Otranto in Italy and the bay on the northern end of Dhermi beach in Albania.

Each cruiser in the survey was monitored during the entire stay in the Adriatic and records were made of the time of entrance and exit from the Adriatic and from each of the four relevant zones of navigation:

ZONE 1: harbour/anchorage: ZONE 1a: Croatian port/ anchorage; ZONE 1b: foreign port/anchorage,

ZONE 2: navigation in the $3 \mathrm{M}$ area,

ZONE 3: navigation in 3 - $12 \mathrm{M}$ area and

ZONE 4: navigation over $12 \mathrm{M}$ from the nearest land, i.e. beyond the territorial sea of the Republic of Croatia.

During the survey images were recorded of all routes of cruisers with entered times of entry and exit from the defined zones of navigation. Images are used to compare the movement of more cruisers on the same routes and to assist in identifying critical areas of navigation. An example of image tracking for one cruiser is shown in Figure 2.
In the year of survey 63 cruisers carrying 500 or more passengers came into the Adriatic Sea. Out of 34 world cruise companies (refers to cruise companies that have two or more cruisers with passenger capacity of 500 or more), the mentioned ships represent 25 of them. During their stay in the Adriatic, cruisers had 21 different ports of call, eleven of which were Croatian. Frequency of cruise ship routes according to ports of call is shown in Table 2. The most frequent destinations for cruisers are Venice with 387 and Dubrovnik with 338 times as a port of call, which is twice more than the third-placed Kotor which was port of call 169 times. Next Bari and Split with over 100 times as a port of call; Zadar with 52; Koper, Brindisi, Trieste, Ravenna, Korčula, Hvar and Ancona with 15-35; Durres with 5 and Rijeka, Rovinj and Šibenik with 4 times as port of call; and four ports with one time as port of call: Bol, Pula, Trogir and Chioggia.

Cruise ships spent a total of $1,814.9$ days in the Adriatic in the observed period: 712.1 days in port and $1,102.8$ days at sea out of which 66.61 days in zone $2,195.78$ days in zone 3 and 840.42 days in zone 4. Distribution and percentage of time in each zone is shown in Table 3.

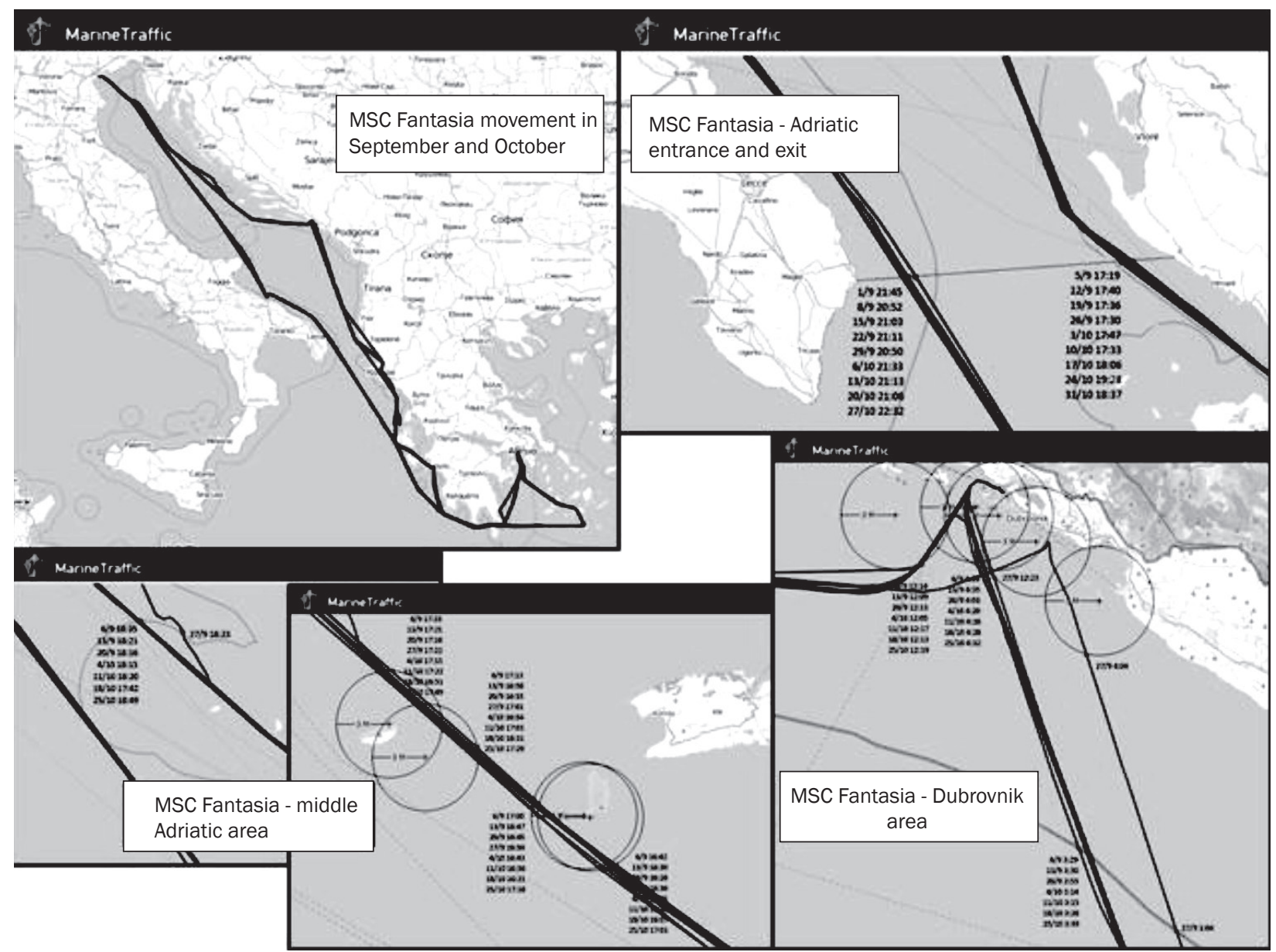

Figure 2 - Image tracking in the case of cruiser MSC Fantasia for September and October 


\begin{tabular}{|c|c|c|c|c|c|c|c|c|c|c|c|c|c|c|c|c|c|c|c|c|c|c|c|c|}
\hline & $\begin{array}{l}\text { әлпұеdәр } \\
\text { o słu!od } 3\end{array}$ & 守 & $\begin{array}{c}\widehat{\infty} \\
\text { m }\end{array}$ & $\hat{m}$ & @્) & $\begin{array}{l}0 \\
\stackrel{9}{\rightarrow}\end{array}$ & 웍 & in & 产 & ले & $m$ & $\stackrel{\sim}{\sim}$ & 尺े & ᄀ & $\stackrel{\llcorner}{\sim}$ & \llcorner & $\nabla$ & $\nabla$ & $\nabla$ & 4 & -1 & -1 & -1 & \\
\hline & $7 ! \times \exists$ & & ष & $\stackrel{10}{0}$ & $\begin{array}{l}\infty \\
\infty\end{array}$ & 웜 & $\vec{m}$ & & & $\stackrel{\Xi}{\sim}$ & $\infty$ & -1 & $\wedge$ & $m$ & & $N$ & & & & & & & & ণ̃ \\
\hline & ย!ดిฉిం!บ৩ & & & & & & & & $-r$ & & & & & & & & & & & & & & $\times$ & -1 \\
\hline & 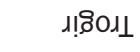 & & & & & & & & & & & -1 & & & & & & & & & & $\times$ & & -1 \\
\hline & eind & & & -1 & & & & & & & & & & & & & & & & & $x$ & & & -1 \\
\hline & גеłədns & & & -1 & & & & & & & & & & & & & & & & $\times$ & & & & -1 \\
\hline & y!uəq!S & & † & & & & & & & & & & & & & & & & $\times$ & & & & & $\nabla$ \\
\hline & ?u!ı০Y & & & $m$ & & & & & & & & & & 4 & & & & $\times$ & & & & & & $\nabla$ \\
\hline & еуәə!! & & $m$ & -1 & & & & & & & & & & & & & $\times$ & & & & & & & $\nabla$ \\
\hline & səuın & $N$ & & $m$ & & & & & & & & & & & & $\times$ & & & & & & & & ص \\
\hline & enosur & & & 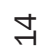 & & & N & & & & & & & & $\times$ & & & & & & & & & ب \\
\hline & ІелH & -1 & $N$ & م & $m$ & & N & 4 & & & & $m$ & & $x$ & & & & & & & & & & ㄱ \\
\hline & હામગ્રિ૦્ર & -1 & $\wedge$ & $N$ & $\sigma$ & & & $\sim$ & & & & & $\times$ & & & & & & $\nabla$ & & & & & $\stackrel{i}{*}$ \\
\hline & еииәлеу & $\sigma$ & $\stackrel{0}{9}$ & $\sim$ & & & -1 & & $m$ & & & $\times$ & & & & & & & & & & & & $\stackrel{\sim}{N}$ \\
\hline & 7511 & & $\stackrel{\llcorner}{\sim}$ & $m$ & & & $m$ & & -1 & & $\times$ & & & & & & & 4 & & & & & & $m$ \\
\hline & !s!pu!̣g & 욱 & $\stackrel{\theta}{A}$ & 4 & $\Lambda$ & & & & & $\times$ & & & & & & & & & & & & & & ले \\
\hline & ıədoy & の & a & $\Lambda$ & & & $N$ & 0 & $x$ & & & & & -1 & & & & & & & & & & ले \\
\hline & ıереZ & & $\vec{f}$ & הี & 0 & & & $\times$ & $m$ & & م & -1 & & -1 & & & & & & & & & -1 & กิ \\
\hline & t!lds & $\stackrel{m}{N}$ & f & -1 & 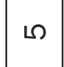 & -1 & $x$ & $\sim$ & -1 & & ᄀ & ம & $\infty$ & & & N & & & & -1 & & & & 곡 \\
\hline & !eg & N & 유 & $N$ & $\sim$ & $\times$ & & & & & \llcorner & -1 & $\nabla$ & & & & & & & & & & & $\underset{\sim}{\mathscr{m}}$ \\
\hline & $1070 \mathrm{y}$ & N & ㅇ & \& & $\times$ & $m$ & N & \llcorner & & N & & $\nabla$ & & 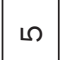 & & 4 & & & & & & $\rightarrow$ & & 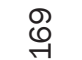 \\
\hline & Y!̣u^oגqna & $\begin{array}{l}\infty \\
\infty \\
\sim \\
\sim\end{array}$ & 요 & $\times$ & $\stackrel{\curvearrowright}{N}$ & $\stackrel{m}{\sim}$ & $\vec{\neg}$ & $\infty$ & $m$ & $\infty$ & $N$ & $m$ & $N$ & $N$ & & & $m$ & & & & & & & $\stackrel{\infty}{m}$ \\
\hline & е!! эәиә & ๙ & $\times$ & - & $\stackrel{\llcorner}{\sim}$ & & ஓ & $\dot{N}$ & N & & -1 & $\wedge$ & $\sim$ & $\nabla$ & $\stackrel{\llcorner}{\sim}$ & & -1 & $m$ & & & -1 & & & $\stackrel{\substack{\infty \\
m}}{\infty}$ \\
\hline 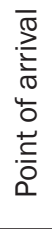 & 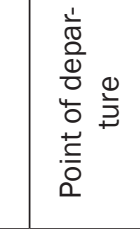 & 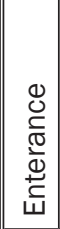 & 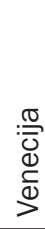 & 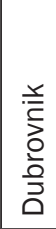 & $\begin{array}{l}\overline{⿳ 亠 丷 厂 巾 ~} \\
\text { aे }\end{array}$ & $\begin{array}{l}\overline{\bar{D}} \\
\infty \\
\infty\end{array}$ & $\begin{array}{l}\frac{5}{\overline{0}} \\
\text { n. }\end{array}$ & $\begin{array}{l}\bar{\pi} \\
\frac{\pi}{0} \\
N \\
N\end{array}$ & $\mid$\begin{tabular}{|}
$\bar{\alpha}$ \\
$\bar{a}$ \\
$\bar{a}$
\end{tabular} & 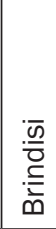 & 焕 & 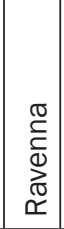 & \begin{tabular}{|l|}
$\frac{\pi}{J}$ \\
$\bar{J}$ \\
$\underline{2}$ \\
$\underline{2}$
\end{tabular} & 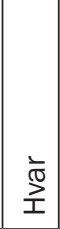 & $\begin{array}{l}\frac{\pi}{2} \\
0 \\
0 \\
\frac{0}{\alpha}\end{array}$ & $\mid$\begin{tabular}{l}
0 \\
0 \\
\multirow{2}{2}{} \\
0
\end{tabular} & 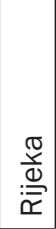 & 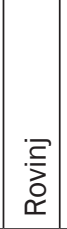 & 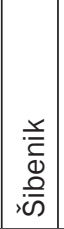 & 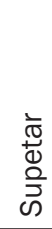 & $\frac{\pi}{3}$ & $\begin{array}{l}: \overline{\overline{c o}} \\
\stackrel{\circ}{\circ}\end{array}$ & $\begin{array}{l}\frac{\pi}{20} \\
.00 \\
. \frac{0}{\bar{\nu}} \\
\end{array}$ & 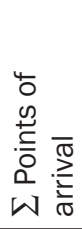 \\
\hline
\end{tabular}


T. Perić, P. Komadina, N. Račić: Wastewater Pollution from Cruise Ships in the Adriatic Sea

Table 3 - Time distribution of cruise ship retention in the Adriatic according to zones of navigation

\begin{tabular}{|c|c|c|c|c|c|c|c|c|}
\hline \multirow{3}{*}{$\begin{array}{l}\text { Zones of } \\
\text { navigation }\end{array}$} & \multicolumn{3}{|c|}{ ZONE 1} & ZONE 2 & ZONE 3 & ZONE 4 & \multirow{3}{*}{$\begin{array}{c}\begin{array}{c}\text { ZONES } \\
(2+3+4)\end{array} \\
\\
\text { Total } \\
\text { navigation }\end{array}$} & \multirow{3}{*}{$\begin{array}{c}\sum \text { ZONES } \\
\text { Total reten- } \\
\text { tion in the } \\
\text { Adriatic }\end{array}$} \\
\hline & \multirow{2}{*}{$\begin{array}{c}\begin{array}{c}\text { Croatian } \\
\text { port/ } \\
\text { anchorage }\end{array} \\
\text { ZONE 1a }\end{array}$} & \multirow{2}{*}{$\begin{array}{c}\begin{array}{c}\text { Foreign } \\
\text { port/ } \\
\text { anchorage }\end{array} \\
\text { ZONE 1b }\end{array}$} & \multirow{2}{*}{$\begin{array}{l}\text { Total port/ } \\
\text { anchorage }\end{array}$} & \multicolumn{3}{|c|}{$\begin{array}{c}\text { MARPOL Annex IV areas of limited } \\
\text { wastewater discharge }\end{array}$} & & \\
\hline & & & & $<3 \mathrm{M}$ & 3-12 M & $>12 \mathrm{M}$ & & \\
\hline $\begin{array}{c}\text { Retention } \\
\text { time [days } \\
\text { hh:mm] }\end{array}$ & $\begin{array}{c}216 \\
23: 31\end{array}$ & $\begin{array}{c}495 \\
02: 41\end{array}$ & $\begin{array}{c}712 \\
02: 12\end{array}$ & $\begin{array}{c}66 \\
14: 37\end{array}$ & $\begin{array}{c}195 \\
18: 51\end{array}$ & $\begin{array}{c}840 \\
10: 00\end{array}$ & $\begin{array}{l}1102 \\
19: 28\end{array}$ & $\begin{array}{l}1814 \\
21: 40\end{array}$ \\
\hline $\begin{array}{l}\text { Percentage } \\
\text { of time }\end{array}$ & 11,95 & 27,28 & 39,23 & 3,67 & 10,79 & 46,31 & 60,77 & 100 \\
\hline
\end{tabular}

\section{MODEL OF CRUISE SHIPS TRAFFIC IN THE ADRIATIC SEA CONSIDERING MARPOL ANNEX IV AREAS OF LIMITED WASTEWATER DISCHARGES}

By tracking of cruise ships in the survey, it was noted that they take predictable navigational routes with respect to the ports of call. Tracking entrance and exit times from the defined navigation zones on specific route between two ports based on more cruisers allows us to formulate equations of movement with respect to the ports of call and retention time in ports. In this way, the results obtained in the survey allow us to forecast the movement of cruise ships in the future which is a key factor for the assessment of marine pollution by sanitary wastewater.

The process of calculating generated sanitary wastewater on a cruiser is shown in Figure 3 and it begins with knowing two input values:

- Passenger capacity of a cruiser for which the calculation is performed, and

- Cruise itinerary with ETA and ETD for each port.

Only upon completion of calculations of generated sanitary wastewater during the stay of cruisers in the Adriatic for each of the zones of navigation, we may proceed to pollution predictions using different scenarios and combinations of operation modes.

The first step in data processing is to calculate the retention time in port (zone 1 ) and retention time in

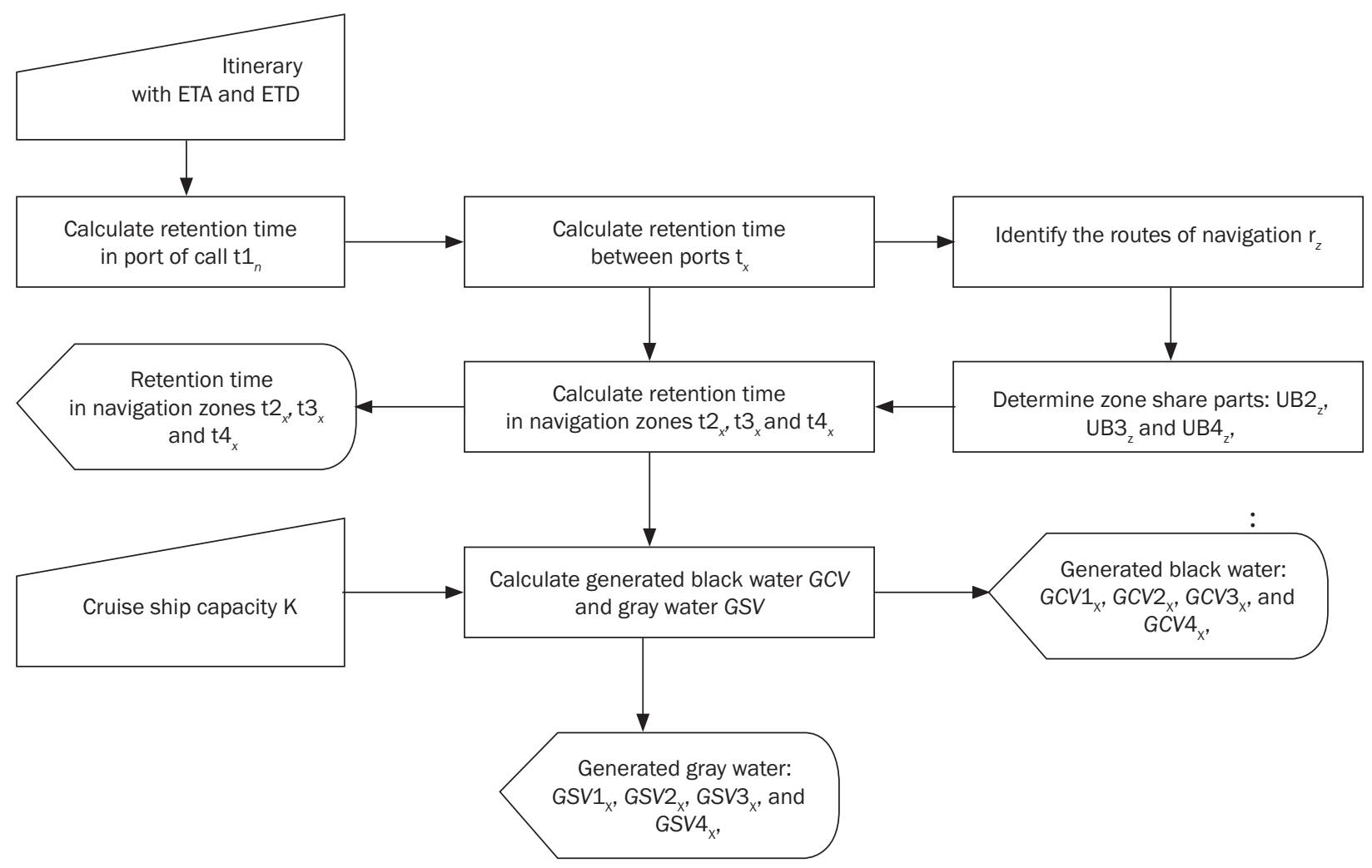

Figure 3 - The process of calculating generated sanitary wastewater on a cruiser 
navigation between ports based on cruise itinerary with ETA and ETD.

On its voyage cruise ship visits $n$ ports of call, where $n=1,2,3 \ldots$ Knowing ETA and ETD, as shown in Figure 4 , it is possible to calculate the retention time in port $t 1 n$ and retention time in navigation between ports $t_{x}$ which is the sum of retention times in navigation zones 2,3 and $4\left(t 2_{x}, t 3_{x}\right.$ and $\left.t 4_{x}\right)$.

Number of voyages between ports of call $x$ is always fewer by one than the number of ports $n$. Taking into consideration the voyage from entering the Adriatic Sea to the first port of call and final voyage from the last port of call to the Adriatic exit, the total number of voyages for a cruise ship in the Adriatic Sea is:

$$
x=n+1
$$

The retention time in port of call can be calculated following the general formula:

$t 1_{n}=E T D_{n}-E T A_{n}$

while retention time in navigation between ports can be calculated following the next general formula:

$t_{x}=E T A_{n+1}-E T D_{n}$

where retention time between the Adriatic entrance and the first port of call $t_{u l}$ and retention time between the last port of call and the Adriatic exit $t_{i z l}$ are obtained by empirical data from the survey.

The total retention time in navigation in the Adriatic $t_{U K}$ is defined as:

$$
t_{U K}=t_{u l}+\sum t_{x}+t_{i z l} \quad \text { for } x=1,2,, n-1
$$

Next step is to identify the routes of navigation. The schedule of routes according to ports of call is already given in Table 3. Based on that schedule, by frequency of use, to each route a symbol is assigned $r_{z}(z=1,2, \ldots, 122)$. Survey data analysis of movement of multiple cruisers on the same route together with their retention times in navigation zones and retention time in navigation between ports allows us to determine the percentage of time spent in each zone for every route $r_{z}$ which is called zone share part with general symbol $\cup B_{Z}$ :

$$
\begin{array}{cccc}
r_{1} & U B 2_{1} & U B 3_{1} & U B 4_{1} \\
r_{2} \leftrightarrow U B 2_{2} & U B 3_{2} & U B 4_{2} \\
\vdots & \vdots & \vdots & \vdots \\
r_{Z} & U B 2_{z} & U B 3_{z} & U B 4_{z}
\end{array}
$$

Zone share part is an arithmetic mean of retention time in navigation zone and retention time in navigation between ports ratio for all ships on the same route. Thus, zone 2 share part $\left(U B 2_{z}\right)$ for route $r_{z}$ is an arithmetic mean of retention time in navigation zone 2 $\left(t 2_{i}\right)$ and retention time in navigation between ports $t_{i}$ ratio for $n$ ships that sailed on this route. Analogously, the following formulas are general formulas for the calculation of zone share part:

$$
\begin{aligned}
U B 2_{z} & =\frac{\sum_{i=1}^{n} \frac{t 2 i}{t_{i}}}{n} \\
U B 3_{z} & =\frac{\sum_{i=1}^{n} \frac{t 3 i}{t_{i}}}{n} \\
U B 4_{z} & =\frac{\sum_{i=1}^{n} \frac{t 4 i}{t_{i}}}{n}
\end{aligned}
$$

Zone share parts $U B 2_{z}, U B 3_{z}$ and $U B 3_{z}$ will also be broken down to geographic areas of navigation for each route. This will allow the knowledge of not only the retention time of cruisers in MARPOL Annex IV areas of limited wastewater discharge, but also the retention time in the defined geographical areas of the Adriatic Sea.

So, when retention time in navigation between ports $t_{x}$ for the voyage $x$ is calculated and that voyage is recognized as route $r_{z}$, with zone share parts $U B 2_{z}$,

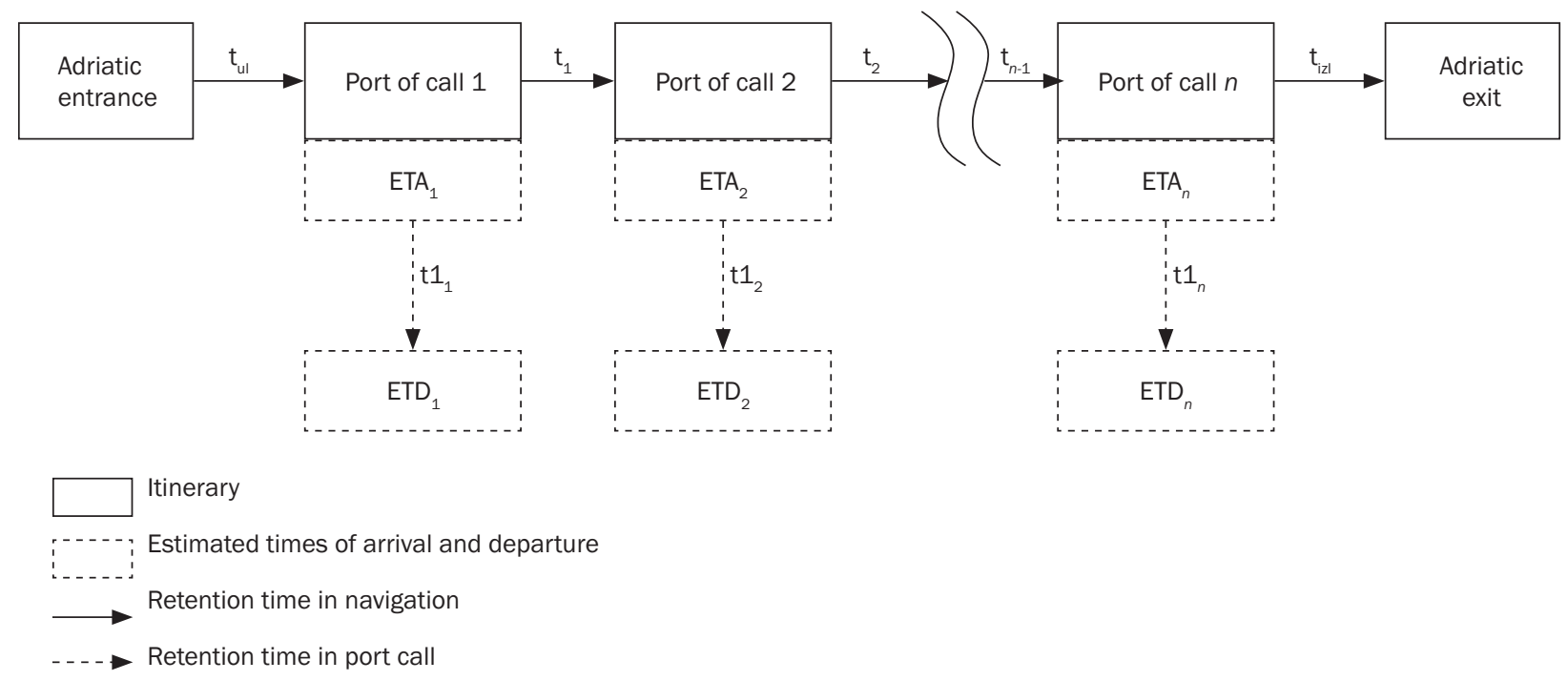

Figure 4 - Calculation of retention time in navigation zones according to ports of call scheme 
$U B 3_{z}$ and $U B 4_{z}$ it is possible to calculate individual retention time in the navigation zones:

$$
\begin{aligned}
& t 2_{x}=U B 2_{z} \cdot t_{x} \\
& t 3_{x}=U B 3_{z} \cdot t_{x} \\
& t 4_{x}=U B 4_{z} \cdot t_{x}
\end{aligned}
$$

By knowing the retention time in navigation zones for a particular route and the number of people on board a cruise ship or its capacity $K$ it is possible to calculate the quantity of generated sanitary wastewater. It has already been said that cruise ship generates an average of 31.8 litres/person/day of black water and 253 litres/person/day of grey water. The equations for generated black water GCV in the navigation zones are as follows:

$$
\begin{aligned}
& \mathrm{GCV}_{1_{x}}=F_{C V} \cdot K \cdot t 1_{n} \\
& \mathrm{GCV}_{2}=F_{C V} \cdot K \cdot t 2_{x} \\
& \mathrm{GCV}_{x}=F_{C V} \cdot K \cdot t 3_{x} \\
& \mathrm{GCV}_{x}=F_{C V} \cdot K \cdot t 4_{x}
\end{aligned}
$$

where $F_{C V}$ is black water factor and it is $1.325 \mathrm{l} /$ person/h.

The equations for generated grey water GSV in the navigation zones are as follows:

$$
\begin{aligned}
& \mathrm{GSV}_{x}=F_{S V} \cdot K \cdot t 1_{n} \\
& \mathrm{GSV}_{2}=F_{S V} \cdot K \cdot t 2_{x} \\
& \mathrm{GSV}_{x}=F_{S V} \cdot K \cdot t 3_{x} \\
& \text { GSV }_{x}=F_{S V} \cdot K \cdot t 4_{x}
\end{aligned}
$$

where $F_{S V}$ is grey water factor and it is $10.54 \mathrm{l} / \mathrm{per}$ son/h.

\section{CONCLUSION}

Cruise ships, because of the nature of their work, have at least one year pre-determined itineraries which provide realistic input parameters for the model presented. The model of cruise ships traffic in the Adriatic Sea considering MARPOL Annex IV areas of limited wastewater discharges allows us to predict the cruise movement in the Adriatic Sea for a chosen period of time and the retention time in zones of limited wastewater discharges for a specific area and to calculate the generated grey and black wastewater by knowing only two input parameters: capacity of the cruiser and itinerary with estimated time of arrival and departure from the port. Using the model, it is possible to know in advance the routes of the cruisers and retention time in certain geographic areas which allow us to calculate the generated wastewater on cruise ships in the Adriatic Sea. Based on these data it will be possible to distribute or to limit traffic in a timely manner, but also to analyze future trends in terms of environmental pollution.

In this way the presented model of cruise ship traffic in the Adriatic Sea considering MARPOL Annex IV areas of limited wastewater discharges is the basis for the development of valuation model of marine pollution by wastewater from cruise ships. However, its application does not stop here; it can be used as the basis for evaluation of other types of pollution from cruise ships or for detailed analysis of cruise ship traffic in the Adriatic Sea.

TINA PERIĆ, mag. ing. ${ }^{1}$

E-mail: tina.peric@pfst.hr

Prof. dr. sc. PAVAO KOMADINA ${ }^{2}$

E-mail: komadina@pfri.hr

Izv. prof. dr. sc. NIKOLA RAČIĆ ${ }^{1}$

E-mail: nikola@pfst.hr

${ }^{1}$ Sveučilište u Splitu, Pomorski fakultet u Splitu

Ruđera Boškovića 37, 21000 Split, Hrvatska

2 Sveučilište u Rijeci, Pomorski fakultet

Studentska ulica 2, 51000 Rijeka, Hrvatska

\section{ONEČIŠĆENJE JADRANSKOG MORA SANITARNIM OTPADNIM VODAMA S BRODOVA ZA KRUŽNA PUTOVANJA}

\section{SAŽETAK}

Globalni rast kruzing turizma donosi sve veću zabrinutost za onečišćenje morskog okoliša. Onečišćenje mora sanitarnim otpadnim vodama je problem posebno izražen na velikim brodovima za kružna putovanja dok se pravna regulativa jednako odnosi prema brodovima trgovačke mornarice koji najčešće imaju do 30 osoba na brodu $i$ brodovima za kružna putovanja gdje broj osoba na brodu može preći 8,000. Da bi bilo moguće vrednovati buduće onečišćenje mora u bilo kojem odabranom periodu vremena potrebno je poznavati kretanje brodova u Jadranskom moru. Ovaj rad prezentira problem onečišćenja mora sanitarnim otpadnim vodama s brodova za kružna putovanja, tehnologiju pročišćavanja istih i daje model kretanja brodova za kružna putovanja u Jadranskom moru s obzirom na područja ograničenog ispuštanja sanitarnih otpadnih voda prema Prilogu IV MARPOL konvencije. Koristeći se modelom moguće je unaprijed poznavati raspored kretanja brodova $i$ vrijeme boravka brodova u određenim geografskim područjima. Podaci dobiveni ovim modelom mogu se koristiti kao ulazni parametri za model vrednovanja onečišćenja Jadranskog mora sanitarnim otpadnim vodama s brodova za kružna putovanja ili za vrednovanje drugih vrsta onečišćenja, kao i za detaljnu analizu prometa brodova za kružna putovanja u Jadranskom moru.

\section{KLUČNE RIJEČI}

kruzing turizam; zaštita okoliša; Prilog IV MARPOL konvencije; sanitarne otpadne vode;

\section{REFERENCES}

[1] Republic of Croatia. Draft strategy for development of tourism until 2020 [in Croatian]. Zagreb: Ministry of tourism; 2013.

[2] Republic of Croatia. Environmental Protection Agency. Report on the environmental situation in the Republic of Croatia [in Croatian]. Zagreb; 2007. 
[3] Koboević Ž, Komadina P, Kurtela Ž. Protection of the Seas from Pollution by Vessel's Sewage with Reference to Legal Regulations. Promet - Traffic \& Transportation. 2011;23(5):377-387.

[4] United States. Environmental Protection Agency. Cruise Ship Discharge Assessment Report. Washington, D.C: Environmental Protection Agency, Office of water; 2008.

[5] International Maritime Organization. International Convention for the Prevention of Pollution from Ships: Annex IV - Prevention of Pollution by Sewage from Ships; 2003.

[6] International Maritime Organization. Marine Environment Protection Committee. Resolution
MEPC.227(64): 2012 Guidelines on Implementation of Effluent Standards and Performance Tests for Sewage Treatment Plants; 2012.

[7] International Maritime Organization. Marine Environment Protection Committee. Resolution MEPC.200(62): Amendments to the Annex of the Protocol of 1978 Relating to the International Convention for the Prevention of Pollution from Ships, 1973 (Special Area Provisions and the Designation of the Baltic Sea as a Special Area under MARPOL Annex IV); 2011.

[8] International Maritime Organization. Marine Environment Protection Committee. Resolution MEPC.157(55): Recommendation on Standards for the Rate of Discharge of Untreated Sewage from Ships; 2006. 